\title{
Confirming a critical role for death receptor 5 and caspase-8 in apoptosis induction by endoplasmic reticulum stress
}

\author{
Mable Lam ${ }^{1} \cdot$ David A. Lawrence ${ }^{2} \cdot$ Avi Ashkenazi $^{2} \cdot$ Peter Walter $^{1}$ \\ Received: 24 April 2018 / Revised: 11 June 2018 / Accepted: 14 June 2018 / Published online: 10 July 2018 \\ (c) The Author(s) 2018. This article is published with open access
}

\begin{abstract}
Several studies implicate specific death receptors (DRs) and caspase-8 in mediating apoptosis in response to endoplasmic reticulum (ER) stress; however, a recent paper challenges this conclusion. Here we validate the importance of DR5 and caspase-8 as critical signal conduits for apoptosis activation upon ER stress.
\end{abstract}

Elucidating the switch between cell survival and apoptosis during ER stress is key to understanding diseases such as protein-folding disorders and cancer [1,2]. Several reports demonstrate a critical role for DRs and caspase-8 in ER stressinduced apoptosis [3-7]. However, Glab et al. [8] recently refuted this by studying cell lines bearing CRISPR knockout (KO) of DR5 or caspase-8. Glab et al. kindly provided their cells to us upon request, and we have analyzed these independently at both of our laboratories. Here we confirm, using their cell lines, that DR5 and caspase- 8 have crucial roles in triggering apoptosis upon in response to ER stress [8].

We induced ER stress with thapsigargin $(\mathrm{Tg})$ and measured apoptosis activation by two orthogonal assays: Annexin V/Sytox Blue staining (Fig. S1A-D) and subG1 DNA content (Fig. S1E). Relative to HCT116 Cas9 parental cells, DR5 KO cells showed partial attenuation, while caspase-8 KO cells exhibited nearly complete inhibition of Tg-induced apoptosis. Consistently, Tg-induced PARP cleavage (evident by the ratio of cleaved to uncleaved PARP, quantified in Fig. S1G), caspase-3 cleavage, and caspase-3/7 enzymatic activity, were

Electronic supplementary material Note that Figure 1 needs to be replaced with attached fileThe online version of this article (https://doi. org/10.1038/s41418-018-0155-y) contains supplementary material, which is available to authorized users.

\section{Avi Ashkenazi}

aa@gene.com

1 Howard Hughes Medical Institute, Department of Biochemistry and Biophysics, University of California at San Francisco, San Francisco, CA 94158, USA

2 Cancer Immunology, Genentech, Inc., South San Francisco, CA 94080, USA diminished in DR5 KO cells and abolished in caspase-8 KO cells (Fig. S1F-H).

We also performed siRNA knockdown against DR5 in Cas9 parental cells. In keeping with published data, DR5 depletion markedly inhibited Tg-induced apoptosis, as clearly indicated by reduced Annexin V/Sytox Blue staining, PARP and caspase-3 cleavage, and caspase-3/7 activity (Fig. S2AF). Transfection of DR5 KO cells with DR5 siRNA had no further effect on $\mathrm{Tg}$-induced apoptosis, verifying an on-target impact of DR5 siRNA in the Cas9 parental cells (Fig. S3AC). Of note, DR5 CRISPR KO suppressed apoptosis less effectively than did DR5 siRNA depletion (compare Figs. S1 and S2). Furthermore, although caspase-8 KO in Cas9 parental cells strongly inhibited apoptosis, caspase-8 siRNA depletion in DR5 KO cells did not (Fig. S3D, E), suggesting that the residual, DR5-independent, apoptosis in DR5 KO cells is also caspase-8 independent. A plausible explanation of these findings is that long-term DR5 ablation by CRISPR has caused the selected cell line to adapt a rewired ER-stressresponsive apoptotic pathway. Caspase-8 KO cells did not display this, perhaps because this enzyme funnels more apoptosis drivers and is therefore more difficult to bypass than DR5. Why we find caspase-8 KO cells to be resistant whereas Glab et al. found these to be sensitive to ER stress awaits further investigation.

Inhibition of $\mathrm{Tg}$-induced apoptosis was also observed upon TALEN-edited KO of DR5 and DR4 [6]. The robust apoptosis inhibition upon acute DR5 depletion and genetic caspase- 8 ablation verified herein demonstrates that the DR pathway is a critical conduit for life-vs-death decisions during ER stress. This principle has now been documented for diverse ER stressors across multiple cell types [9]. In keeping with this conclusion, both our published results [3] 
and those of Glab et al. [8] implicate the BH3-only protein Bid, whose key proteolytic trigger is caspase-8, in ER stress-induced apoptosis.

\section{Compliance with ethical standards}

Conflict of interest The authors declare that they have no conflict of interest.

Open Access This article is licensed under a Creative Commons Attribution 4.0 International License, which permits use, sharing, adaptation, distribution and reproduction in any medium or format, as long as you give appropriate credit to the original author(s) and the source, provide a link to the Creative Commons license, and indicate if changes were made. The images or other third party material in this article are included in the article's Creative Commons license, unless indicated otherwise in a credit line to the material. If material is not included in the article's Creative Commons license and your intended use is not permitted by statutory regulation or exceeds the permitted use, you will need to obtain permission directly from the copyright holder. To view a copy of this license, visit http://creativecommons. org/licenses/by/4.0/.

\section{References}

1. Tabas I, Ron D. Integrating the mechanisms of apoptosis induced by endoplasmic reticulum stress. Nat Cell Biol. 2011;13:184-90.
2. Wang M, Kaufman RJ. Protein misfolding in the endoplasmic reticulum as a conduit to human disease. Nature. 2016;529:326-35.

3. Lu M, Lawrence DA, Marsters S, Acosta-Alvear D, Kimmig P, Mendez AS, et al. Opposing unfolded-protein-response signals converge on death receptor 5 to control apoptosis. Science. 2014;345:98-101.

4. Iurlaro R, Püschel F, León-Annicchiarico CL, O’Connor H, Martin SJ, Palou-Gramón D, et al. Glucose deprivation induces ATF4mediated apoptosis through TRAIL death receptors. Mol Cell Biol. 2017;37:e00479-16.

5. Chen P, Hu T, Liang Y, Li P, Chen X, Zhang J, et al. Neddylation inhibition activates the extrinsic apoptosis pathway through ATF4CHOP-DR5 axis in human esophageal cancer cells. Clin Cancer Res. 2016;22:4145-57.

6. Dufour F, Rattier T, Constantinescu AA, Zischler L, Morlé A, Ben Mabrouk $\mathrm{H}$, et al. TRAIL receptor gene editing unveils TRAIL-R1 as a master player of apoptosis induced by TRAIL and ER stress. Oncotarget. 2017;8:9974-85.

7. Yamaguchi $\mathrm{H}$ et al.. CHOP is involved in endoplasmic reticulum stress-induced apoptosis by enhancing DR5 expression in human carcinoma cells. J Biol Chem. 2004;279:45495-502.

8. Glab JA et al. DR5 and caspase- 8 are dispensable in ER stressinduced apoptosis. Cell Death Differ. 2017;24:944-50.

9. Muñoz-Pinedo C, López-Rivas A. A role for caspase-8 and TRAIL-R2/DR5 in ER-stress-induced apoptosis. Cell Death Differ. 2018;25:226. 